\title{
Proximity and Distance
}

\author{
Time and Space in Norwegian Newspaper Articles \\ about the World 1880-1930
}

\author{
Anne Hege Simonsen
}

\begin{abstract}
This article shows the great interest in foreign affairs and other international influences in three Norwegian newspapers between 1880 and 1930. International coverage has received relatively little interest in Norwegian press history, but should be considered a vital element in creating a national imagery in a young state which gained its independence in 1905. The article shows how proximity and distance are political as well as geographical concepts, contributing to our notions about social dynamics in other societies. The article is based on a pilot study conducted on behalf of the Norwegian Press History project.
\end{abstract}

Keywords: press history, journalism, foreign news, time, space, nationalism

\section{Introduction}

We all live in small worlds, all by ourselves, out of which nobody escapes but in his imagination. Anything that concerns ourselves and our own interests is reserved the most prominent position. Normally our closest surroundings come next, but somewhat further away from our spiritual vision, everything gets more and more obscure, and on the horizon we can barely distinguish anything. (Lillesands-Posten 25.04.1930)

People organize their interests spatially. If we are to believe this quote from a Norwegian emigrant in the United States, anything within immediate reach is more interesting than whatever goes on in the obscure distance. The author bases his reflections on his own experiences, sharing them with his former local newspaper Lillesands-Posten in the southern part of Norway. In a long letter to the editor he contemplates what kind of stories the press in general chooses to highlight, as well as what he could write that might possibly be of interest to the Lillesand audience. His conclusion is that American politics and everyday life is of limited value. It is better, he decides, to write about the labour market, since so many Norwegians have migrated or thought about migrating to the United States.

This might be an early example of a so-called "Norwegian angle" in Norwegian foreign reporting - a well-known technique used by the media to bring distant events closer. The presence of a fellow countryman/woman makes a catastrophe or a political event 
more relevant to the media, because he or she gives the audience someone to identify with. And without identification, why should anybody care about distant places?

Before 1930, however, such identification by proxy was not a prominent feature in the Norwegian press. Understanding the world, on the other hand, was an area of major importance to the newspapers, and the coverage of international affairs was the pride of any serious editor, particularly after Norway gained independence from Sweden in 1905. What the commentator in Lillesands-Posten also points out to us is that the press presents and represents the world based on domestic concerns. There is an axis between proximity and distance that needs to be considered if we want to understand how newspapers organize their concepts of the world. The quote from Lillesands-Posten, as well as other newspaper reports, shows that people and places do not have fixed positions on this axis. What is close and what is distant are matters in constant flux, even if the movements are slow and seldom random.

\section{An Everyday Approach}

This article is based on some of the findings from a survey of three Norwegian newspapers, Morgenbladet, Norske Intelligenssedler and Lillesands-Posten, between 1880 and 1930. The research question guiding the study was "How was the world presented to Norwegian newspaper audiences?" This question is particularly relevant to understand a period that was seminal not only for the Norwegian press, but also the nation state. As Benedict Anderson (1983) has pointed out, nationalism was the sign of the times and to a large extent newspapers contributed to the creation of the symbolic borders of the nation. In Norway this is specifically highlighted when the Swedish-Norwegian union is dissolved in 1905. Through the newspaper reports we can witness how notions about proximity and distance change according to the current understanding of the nation. Imagining a national community however also implies imagining others (e.g. Lien 1997) and understandings of time and space play a decisive role in these processes.

Norwegian press history has traditionally been focused on the coverage of domestic affairs, and apart from international events with a great impact on Norwegian foreign policy, in particular the Second World War, there have been few systematic studies of international representations in Norwegian newspapers. The point of departure for this study is the everyday coverage of both smaller and larger events related to the international scene and should thus be considered a pilot study, trying to identify interesting areas for further investigation. The chosen newspapers represent the two major political forces in the research period. Norske Intelligenssedler ${ }^{2}$ is the oldest Norwegian newspaper, and one of the main papers in the Norwegian capital Christiania (later Oslo). It was also an important outlet for the oldest political party in the country, Venstre (the Liberal party). Its most significant competitor was Morgenbladet, the biggest newspaper in Christiania/Oslo during this period as well as the mouthpiece for the second oldest political party in Norway, Høyre (the Conservative party). Norske Intelligenssedler was published six days a week, whereas Morgenbladet published one, sometimes two morning editions in addition to its evening paper seven days a week. The exception was Mondays, when they only printed in the evening. The third paper in the survey, Lillesands-Posten, is a local paper published in the southern part of Norway. Lillesands-Posten was a weekly in 1880 and 1890, later becoming a bi- (and sometimes tri-) weekly publication for the rest of the survey period. This paper was chosen because it represents the news priorities in a poor coastal community dependent upon shipping and with a high percentage of emigrants. 
The method used is the so-called synthetic year, selecting the first Monday in January, the second Tuesday in February, the third Wednesday in March and so on. This method has the advantage that it gives a hint about the everyday coverage, instead of having to choose between events that may look quite different from today's perspective than they did when they were published. The disadvantage is that several significant events are not covered by the survey. In each selected edition all articles, or journalistic entries, have been registered to be able to say something about the total amount of foreign coverage in the newspaper in question.

The period covered is also interesting from a genre historical perspective and it has not been easy to categorize entries as either "fillers", news articles or commentaries. During the first decades the categories are particularly blurred, but they become more consistent with modern newspaper production standards at the end of the research period. The years from 1880-1930 are formative ones in Norwegian press history and we can also see significant changes regarding newspaper production technology. The newspapers grow steadily, along with their readership.

It is important to notice that the survey is not limited to the coverage of foreign politics, but tries to account for the complete coverage of international relations, including e.g. cultural entries, trade and tourism reports and curios. From a discourse analytical point of view, one finding is that quite a few of the most telling articles belong to this last category.

Looking at how Morgenbladet, Norske Intelligenssedler and Lillesands-Posten covered the world, we find that in 1880 and 1890 , more than 50 per cent of the articles deal with foreign countries in one way or another. In the last years of the survey, the number goes down from around 40 percent to 32 per cent in 1930 (see table 1), which is still a fairly high figure.

Table 1. Coverage Mentioning Foreign Affairs, Countries or Phenomena, Represented as Percentage of the Total number of Articles

\begin{tabular}{rrrrrrrrr} 
& \multicolumn{2}{c}{ Morgenbladet } & \multicolumn{2}{c}{ Intelligenssedler } & \multicolumn{2}{c}{ Lillesands-Posten } & \multicolumn{2}{c}{ Total } \\
& $\%$ & N & $\%$ & N & $\%$ & N & $\%$ & N \\
\hline 1880 & 58 & 160 & 59 & 64 & 38 & 58 & 53 & 282 \\
1890 & 56 & 306 & 53 & 244 & 35 & 79 & 51 & 629 \\
1900 & 49 & 356 & 33 & 111 & 37 & 57 & 43 & 524 \\
1910 & 44 & 366 & 33 & 120 & 28 & 60 & 39 & 546 \\
1920 & 49 & 402 & 42 & 205 & 27 & 70 & 43 & 677 \\
1930 & 31 & 176 & 32 & 183 & 35 & 91 & 32 & 450 \\
Total & 47 & 1766 & 40 & 927 & 33 & 415 & 42 & 3108 \\
\hline
\end{tabular}

The high number of entries about foreign issues during the first half of the survey can be linked to the fact that international wire services were cheap. Norway, on the other hand, was a long and not easily accessible country with poor infrastructure. One should, however, not underestimate the urban readership's interest in international affairs and phenomena. The survey period was characterised by powerful technological revolutions as well as intense Norwegian activity on the international scene. We find massive migration, mainly to the United States, while shipping, whaling and fishing were important sources of income. In addition there is budding industrialization, to a great extent assisted by foreign, and in particular German, actors. 
Last, but not least, Norway changed its international status from a semi-colony under Sweden to a new, sovereign nation state. Because of the union, Norwegian foreign policy was not very advanced, and Norway kept a low international profile particularly regarding security issues. Jørgen Løvland, Norway’s first foreign minister, is often quoted as saying that "we will not have any foreign policy", a quote that must be understood in context. It does not mean that Norway was not interested in a foreign policy but rather implies that the government prioritized trade and conflict arbitration in international relations.

As both table 1 and 2 show, the number of articles declines during the survey period (1920 is the exception, probably due to the aftermath of the First World War). It is important to note that the decline in numbers does not necessarily equal a smaller interest in international issues. A number of factors can account for the decline, such as new technology making it easier to print a growing number of pages (from four to twelve in some of the papers) as well as making domestic affairs more accessible to the newspapers.

Table 2. Coverage of Foreign Affairs (political news stories and analysis), Represented as Percentage of Total Number of Articles

\begin{tabular}{rrrrrrrrr} 
& \multicolumn{2}{c}{$\begin{array}{c}\text { Morgenbladet } \\
\end{array}$} & \multicolumn{2}{c}{ Intelligenssedler } & \multicolumn{2}{c}{ Lillesands-Posten } & \multicolumn{2}{c}{ Total } \\
\hline 1880 & 30 & 82 & 43 & 46 & 20 & 30 & 30 & 158 \\
1890 & 34 & 185 & 39 & 177 & 35 & 79 & 33 & 414 \\
1900 & 30 & 216 & 21 & 69 & 26,3 & 41 & 27 & 326 \\
1910 & 24 & 201 & 24 & 88 & 16 & 35 & 23 & 324 \\
1920 & 33 & 272 & 23 & 111 & 19 & 48 & 27 & 431 \\
1930 & 13 & 73 & 14 & 80 & 23 & 60 & 15 & 213 \\
Total & 27 & 1029 & 25 & 571 & 23 & 293 & 25 & 1866 \\
\hline
\end{tabular}

It is also reasonable to believe that the dissolving of the Swedish-Norwegian union contributed to a new interest in the newly born nation state and its future, both on the national and the international scene. The newspapers actually invested more in their foreign coverage after the union ended, even if the percentage of foreign coverage was reduced. Obviously, a network of correspondents all over the world was more costly than letting someone cut stories from the wire services with a pair of scissors.

\section{"All the Important Events in the Whole Civilized World"}

From a 2008 perspective it is amazing to see to what extent newspapers flattered themselves by showing off their prominence in international news. In 1910, Norske Intelligenssedler (later Tidens Tegn/Verdens Gang) used the front page to tell their readers that they were expanding the foreign news section with "telegraph correspondents" in Copenhagen, Berlin, London, Paris, St. Petersburg and New York.

National correspondents played an important role establishing a solid contract between the newspaper and the local readership, but the icing on the cake was the broad coverage of international affairs. Intelligenssedlene claimed that their goal was to provide the readers with "all the important events in the whole civilized world, the same moment they are known to the big metropolises." (Norske Intelligenssedler 04.01.1910) 
In 1920 Morgenbladet promoted itself on the front page of the evening edition claiming that one of the main reasons for taking the paper was that the coverage of foreign affairs was getting even better than before:

A trustworthy, up to date and comprehensive daily newspaper is the household's best friend. Morgenbladet has better and more detailed foreign telegrams than any other Norwegian newspaper. Through daily telegrams and weekly letters from our offices in London, Paris, New York, Berlin and Rome, Morgenbladet keeps its readers informed about political and economic affairs throughout the world. Permanent correspondents in Rotterdam, Vienna and Helsingfors [the Swedish name for Helsinki] as well as in Sweden and Denmark, bring information about any newsworthy event. Morgenbladet has secured the Norwegian rights to telegrams from the Central News Bureau. One staff member is sent to Vienna to study the famine in Austria and how to fight it. Another is sent to Peru to portray this interesting but not very well known country, in addition to exploring the possibilities for Scandinavian exports to the western coast of South America. (Morgenbladet 05.01.1920)

How should we understand the world presented to us by the press? Even if many Norwegians were engaged in shipping, and international trade and migration to the United States was among the highest in Europe, most people did not have first hand experience with foreign countries. Still, they were influenced by international, even global phenomena in several ways.

The Austrian-American phenomenologist Alfred Schütz (1899-1959) points out that the way we relate to everyday life is basically ruled by pragmatic motives. Our surroundings should be seen first and foremost as a practical framework, shaping our minds as such. The main topics addressed by Norwegian newspapers were politics and trade, and we could thus argue that the international coverage is guided by a pragmatic attitude towards the world. Trade and political analysis are practical tools to steer by in the murky waters of the world, and the pragmatic bias in the survey material is confirmed by the fact that there are remarkably few differences in how the liberals and the conservatives in Norwegian politics analysed international affairs. Geographical location (capital vs. district) was in many ways more important than political affiliation as regards how the world was portrayed to the newspaper readers.

Table 3. Topics Covered, Represented as Percentage of the Total Number of Foreign Entries

\begin{tabular}{|c|c|c|c|c|c|c|c|c|c|c|c|c|c|c|}
\hline & \multicolumn{2}{|c|}{1880} & \multicolumn{2}{|c|}{1890} & \multicolumn{2}{|c|}{1900} & \multicolumn{2}{|c|}{1910} & \multicolumn{2}{|c|}{1920} & \multicolumn{2}{|c|}{1930} & \multicolumn{2}{|c|}{ Total } \\
\hline & $\%$ & $\mathrm{~N}$ & $\%$ & $N$ & $\%$ & $\mathrm{~N}$ & $\%$ & $\mathrm{~N}$ & $\%$ & $\mathrm{~N}$ & $\%$ & $\mathrm{~N}$ & $\%$ & $\mathrm{~N}$ \\
\hline Politics & 38,3 & 108 & 40,5 & 255 & 48,3 & 253 & 32,2 & 176 & 50,7 & 343 & 26,0 & 117 & 40,3 & 1252 \\
\hline Trade & 29,4 & 83 & 20,8 & 131 & 16,2 & 85 & 15,0 & 82 & 19,5 & 132 & 24,0 & 108 & 20,0 & 621 \\
\hline Culture & 12,1 & 34 & 11,8 & 74 & 14,7 & 77 & 15,0 & 82 & 10,6 & 72 & 17,6 & 79 & 13,4 & 418 \\
\hline Technology & 0,7 & 2 & 2,1 & 13 & 3,1 & 16 & 8,0 & 44 & 3,1 & 21 & 3,8 & 17 & 3,6 & 113 \\
\hline Accidents & 10,3 & 29 & 6,0 & 38 & 4,8 & 25 & 7,7 & 42 & 3,4 & 23 & 8,0 & 36 & 6,2 & 193 \\
\hline Crime & 1,4 & 4 & 4,8 & 30 & 2,9 & 15 & 5,3 & 29 & 2,2 & 15 & 3,3 & 15 & 3,5 & 108 \\
\hline Other & 7,8 & 22 & 14,0 & 88 & 10,1 & 53 & 16,7 & 91 & 10,5 & 71 & 17,3 & 78 & 13,0 & 403 \\
\hline Total & 100 & 282 & 100 & 629 & 100 & 524 & 100 & 546 & 100 & 677 & 100 & 450 & 100 & 3108 \\
\hline
\end{tabular}

The exception is international events that for some reason or other became directly relevant to domestic debates in Norway. One example is Norwegian relations with Swe- 
den before independence. The Høyre (Conservative) paper Morgenbladet supported the political union while the Venstre (Liberal) paper Intelligenssedlene was fiercely opposed. The Boer War in South Africa (1899-1902) is another example, as the war was largely covered from the perspective of the Norwegian-Swedish union as well as the ongoing debate in both countries about the international role of small countries. Morgenbladet supported the British army, and Intelligenssedlene and Lillesands-Posten supported the Boers, whom they portrayed as simple peasants fighting for their sovereignty - a little bit like the Norwegians themselves.

\section{Measuring Time and Space}

Like today, the press from 1880-1930 aimed at providing the public with the most important, the most recent and the most essential news. The choices they made tell us something about what they considered important. Every single day the world contracts or expands according to the movements of the media searchlight. "News is history's second arm", says Anders Johansen, using the clock as an image. He adds that staring at the hour hand of the clock gets you nowhere: "The hour hand is always still, until the moment we realise that it has moved." (Johansen 1997: 93)

Benedict Anderson uses the modern novel as a metaphor for modern newspapers, and calls them "extensively fictional cultural products" because they lump together a random selection of stories with no other visible common denominator than coexistence in time. Anderson is well known for his thesis that newspapers and information capitalism were important contributors in the creation of political imagined communities - in particular nation states - because they tied together people who would never meet face to face and gave them common references. But Anderson claims that also the connection between the news presented by the newspapers is imagined:

The date at the top of the newspaper, the single most important emblem on it, provides the essential connection - the steady onward clocking of homogeneous, empty time. Within that time, 'the world' ambles sturdily ahead. The sign for this: if Mali disappears from the pages of The New York Times after two days of famine reportage, for months on end, readers do not for a moment imagine that Mali has disappeared or that famine has wiped out all its citizens. The novelistic format of the newspaper assures them that somewhere out there the 'character' Mali moves along quietly, awaiting its next reappearance in the plot... (Anderson 1991:33)

If we look at nation states as characters in a novel or alternatively actors on a stage, we can further develop Anderson's metaphor by saying that the roles these characters are playing are more or less predetermined in the narrative the newspaper conveys. These roles are not static, and when we focus on the hour hand of the clock, we can see when the framing changes.

The way for instance Germany is covered shows how the role description can alter according to political development. At the end of the $19^{\text {th }}$ century Germany was presented as a cultural stronghold as well as an expanding superpower. Between the First and the Second World Wars the country became synonymous with political chaos and unrest. The United States shows the opposite movement. From being portrayed as first and foremost a haven for Norwegian emigrants, the country gradually becomes a more and more influential actor in the international arena, linked to everything that's biggest, newest and best. 
Foreign news is thus less news oriented than it is often presented as being. Most international states are only interesting to the news media when they behave "according to character". If something completely new happens, the media takes a long time reframing the cast to make it fit the new reality. The media presents different parts of the world as if they belonged to different periods in time, and if we draw an axis between proximity and distance this corresponds with different notions of time and time's dynamics. As we shall see later, the material shows how certain parts of the world are never measured by the second hand, making them appear more static and stationary than the countries and regions being covered on a daily basis.

\section{The Newspaper as Contemporary}

For the record, what has so far been described as a kind of role casting, for instance the portrayal of Germany's raise and fall, should not be considered as fictional constructs by imaginative news editors. The political, economic and technological changes described by the newspapers are most definitely real, and there is no need to doubt the news editors' sincerity in their wish to present an accurate account of contemporary life. In the spirit of Anderson we need to stress that imagined communities do not equal fantasy communities. The point is that all communities are imagined in one way or another. From this we can argue that to talk about newspapers as fiction is an observation on two levels: The first level is how the newspaper article, understood as a representation of real life, must be seen as a specific cultural abstract, produced within the framework of narrative conventions changing over time.

The second level is how the newspaper as a whole - meaning both content and presentation (layout) - can be read as a semiotic sign within a bigger context, in this case a history of Norwegian modernity. The press does not only write about contemporary life, it is contemporary life. The number of pages, the choice of subjects, the readership, the area of use, even the market shares are results of technological, political, social and economic realities. Newspapers are thus more than information containers, they are also calendar pages, time machines, institutions, organizations, social micro cosmoses, serials, rituals and witnesses.

Historians see newspapers both as accounts and remnants, and press historians have noticed how the press can be agents for social and political change as well as a way of understanding the social production of news (Tjelmeland 2004). The historical dimension, meaning the time gap between the point in time when an article was printed in a newspaper and the way it is read today, gives additional knowledge.

The world presented to the readers in 1880 is not the same world as the one portrayed in 1930, even if the "casting" is more or less the same. The readers and the journalists are of course not the same either, nor are the realities they describe. This is why it is important to keep in mind that this kind of historical material cannot be compared normatively (e.g. if the coverage of the world was better earlier). Comparing the different years quantitatively thus has limited value, except to provide a direction in the material. The qualitative survey is however squeezed between several time dimensions that all together constitute quite a few sources of error.

When we ask questions of historical newspaper texts it is also important to keep in mind that we do this, not only because the texts represent the past, but because they actually exist here and now. As Ricoeur puts it, documents (including newspaper texts) must be considered physical "footprints", and as such they can be seen as "remnants of 
the past, the same way we speak about remnants of a meal, relics of a saint or the ruins of historical monuments".

Such footprints (or traces), says Ricoeur,

$\ldots$ are remnants to the extent that they still exist, while the historical context people, institutions, actions, passions - no longer does... On a different, nonethical level, the trace exists only for those who can treat the mark as a present sign of a non-present thing, or better, as a present remnant of something that no longer exists. Thus the sign becomes a present thing representing a distant past. And this is the true enigma of the trace. What makes it enigmatic is the overlap between a casual connection and its significance. To pursue a footprint, to follow it backwards, is, practically speaking, to merge its two sides and to constitute it as a sign-effect. The consequences of time are considerable; to follow a trace is to mediate between the no longer of the disappeared and the even now of the mark. From this we can say that the past is not only the negatively put bygones, the past is what has been and through its being has been preserved. (Ricoeur and Ystad 1999:169, my translation.)

To trace history's footprints is a way of trying to understand a different time, not forgetting that the trace can never fully be understood independently of its days. Nor should we forget that our questions to the remnant - the newspaper texts - are formulated today and cannot be understood independently of the time in which we live. We cannot expect from old newspaper texts that they can answer why the international news coverage seems less extensive and less varied in 2006 than in 1890 for example. As a sign, however, the trace transcends time through physical and ideological/discursive relations of production. Old newspaper texts can thus give present day news production a genealogy, even in contemporary discursive fields.

\section{The Fragmentation of Time}

The metropolis is illuminated. Lamps and lights in hundreds of thousands. And huge, living snakes of fire twist and turn along the rooftops, circling the names of the greatest companies in the world like the tongues of a multicoloured flame. The best tea in the world, the best whisky in the world, the best wheat flour in the world, the best fabric in the world, the best tobacco in the world. (Morgenbladet 10.07.1910)

In 1910 the Norwegian writer Thomas Krag lived in Berlin and wrote a personal column in Morgenbladet on a regular basis. The illuminated metropolis impressed and fascinated him, but it also made him reflect upon the consequences of modernity, in particular the way it affected the book and human knowledge:

... the spacious hour, the long days, the peaceful evenings are soon gone. The paraffin lamp, that burned so patiently for people sitting quietly at home with their work is almost impossible to get hold of, at least in the big, fashionable magazines. They have electrical lamps in all shapes, lamps for quick work, office lamps for toil and moil, lamps for sparkling parties, lamps and lights for the big restaurants, the theatre shows, the big magazines. An old man studying by his old fashioned lamp - well - let him sit. Of course, we respect him, good heavens, but... The metropolis pays him no heed anyway. At the end of the day he isn't really a part of its life... (ibid) 
The first electric lamp was offered for commercial sale in 1879, and has been called the greatest revolution in the history of man since the taming of fire. The lamp blurred the distinction between night and day, with obvious consequences for industrial production and the work force. Still, electricity was only one of a number of technological innovations that marked the last part of the $19^{\text {th }}$ century as well as the first part of the $20^{\text {th }}$. Through standardization, bureaucratization, rationalization, nationalization, democratization and colonization, the world became smaller and more accessible than ever before. To live in the moment became a saying, and those who didn't keep up with technology were losers, as this article from Lillesands-Posten in 1880 points out:

Steamships [...] continue to expand their territory on the seven seas and from the West Indies, Brazil and the East Asian waters we receive accounts about the steam engine's victory over sail. It is unavoidable that Norwegian ship owners will be put in a worrying, even dangerous position in the long run if they don't take advantage of the signs of the times... The enterprising ship owners in the villages in Romsdal, Bergen and Stavanger have done this and thus secured that the main part of their fish export to Spain, Portugal, the Mediterranean remained under the Norwegian flag... (Lillesands-Posten 08.01.1880)

To live in times so visibly changing, contradictory and ruled by man (as opposed to God) was something fairly new, and one of the main tasks for the newspapers was to identify the signs of the times. News connected different geographical places and tied them together within a common time frame in a completely new manner. Gone was the beginning of the $19^{\text {th }}$ century when news from abroad came by ship and was delivered to the newsrooms in "geographical bundles" (Johansen 1995:127):

Because all information from remote locations was considered interesting, the bundle was opened, and its contents communicated without any significant editing - as a varied, and to the modern reader, quite confusing mixture of reports about extraordinary and highly routine events. (Ibid)

According to Johansen by the end of the $19^{\text {th }}$ century newspapers had reached a level of "non-place" that Benedict Anderson seems to demand in order to define a level of "modern co-existence". This survey somewhat modifies this argument. The news agencies did standardize the media language and made the sentences shorter and more efficient to save costs. Furthermore we also see great differences between the reports from agencies and the letters (or telegrams) from correspondents who might be private contributors, writers or journalists contacted by the newspaper. The relation between the text and its place of origin continues, however, to mark the news coverage throughout the research period, even as late as in 1930. Sometimes the actual news is only a line or two, while the description of how the news item has travelled the world takes almost as much space:

London $10^{\text {th }}$ of October. - According to information from Reuter's in New York who received a telegram from Peking $7^{\text {th }}$ of October: The emperor's widow has fallen seriously ill... (Morgenbladet 10.10 .1900$)^{3}$

\section{Sweden: Close But Distant}

The closer we get to our nearest surroundings, the quicker the second hand on the clock moves, and the way a society is depicted becomes more and more dynamic. In the sur- 
vey material, political debates and parliamentary shuffles in England, Germany, France and Denmark are to a large extent described without any explanatory analysis, as if it is goes without saying that Norwegian citizens had first hand knowledge of the political elite in every European country. Sweden, however, is an interesting exception, because the political life in Sweden is hardly mentioned in the first part of the survey, before Norwegian independence in 1905. The way Sweden was covered in Norwegian newspapers is a good example of how geographical proximity does not necessarily guarantee that an area is socially defined as close.

Sweden is Norway's closest neighbour, and culturally as well as linguistically the two countries could be described as siblings. A first glance at the quantitative part of the material tells us that Sweden gets greater coverage than Denmark in the years before independence, but a second glance reveals that an important number of these articles consist of short fillers about the Swedish-Norwegian king going hunting, inaugurating a new railway in Norway or opening Christmas presents with his family in Stockholm. The political and cultural Sweden is hardly covered at all, interestingly enough irrespective of whether we talk about union-friendly newspapers or those opposed to it. The coverage of Denmark has a very different flavour. Morgenbladet had correspondents in Denmark writing long, and sometimes quite tedious articles about Danish parliamentary skirmishes or analyzing Danish society. If a new play or opera opened in Copenhagen, the Norwegian newspapers covered it as if it was happening in Christiania/Oslo, usually side by side with cultural events from the Norwegian capital.

Norway's nearest neighbour is in other words hardly visible on the axis between proximity and distance, and it is hard to find another explanation for this than some more or less conscious denial of political realities. Lillesands-Posten, located in the far south and thus farther away from Sweden geographically, interestingly described the country as much closer than the Christiania/Oslo press, probably because of its maritime preferences. Norwegian ships often used Swedish ports of refuge, and Lillesands-Posten prioritized naval affairs in general. For example the paper wrote with great passion about the working conditions for all sailors throughout the world.

Lillesands-Posten also shows a closer relation to the United States than the other two, again indicating that the world was constituted differently from the capital than in other parts of the country. In 1880 we find this story about Norwegians in Chicago, and how hard it is for immigrants to find work:

It is difficult for people with no trade. Many dream about a position in a shop or an office. Many have done the only sensible thing and taken what comes their way. Several Norwegians with an education, clerks, pharmacists etc, are paving the streets. (Lillesands-Posten 23.12.1880)

In their former local paper, the emigrants would also often report about everything from Christmas parties to homesickness and expensive food:

Food is expensive in America and it gets more expensive. Overall, the food prices have gone up one fifth compared to six years ago. And clothes are up by one half. Salaries are big in America, but those who consider coming here should think twice, for a lot of what comes in goes out. So the profit doesn't really get very big. (Lillesands-Posten 23.12.1910)

Even in Morgenbladet we find practical advice for Norwegians wanting to pursue a new future in the land of their dreams. As late as in 1930 a Norwegian woman based in the 
US writes about how bad she feels about all the young Norwegian girls who arrive looking for work without even knowing the language.

In general, the newspaper coverage of "America" also shows us how a sense of proximity grants a greater acceptance of ambiguity. In all three papers the USA is described as the country with the biggest restaurants in the world, the longest tunnels, the first, best and foremost, a place where miracles happens. Intelligenssedlene reports how eight and a half million telephone calls are made daily in New York! At the same time they all write about how all these technological wonders are reasons for growing unemployment, and how USA also has the biggest crime arena in the world, full of rabies infected dogs and other horrors.

\section{Time and the Contemporary}

It is often pointed out that one major consequence of the new information technology was a new experience of time as contemporal. When the Titanic sank on the $14^{\text {th }}$ of April 1912, "everybody" followed the event. This was the first time a catastrophe was directly transmitted by telegraph, and to all the corners of the world. Information technology expanded what Schutz calls Mitwelt, or the amount of contemporaries. ${ }^{4}$

Newspaper reports from distant regions show, however, the limits to who could be perceived as belonging to this new and expanded group of contemporaries. One example is given by Morgenbladet's reporter L.L. He visited Egypt in 1910, where he witnessed a march by religious dervishes performing public self-torture. They beat themselves with spike-ended whips and the sound as well as the sight was both strange and nauseating to the journalist. In the article he comforts himself by telling the readers that this is but a passing phase: "The Chiits [Shias] are no more than a few hundred people and the advancing civilisation will soon make them disappear..."

The notion that different societies were located on different steps of the human development ladder was a view consolidated in this period. It followed from the new ways of perceiving time and space, as well as how these perceptions could be linked to the notion of development.

Knut Nustad (2003) shows how development as a concept is intimately linked to the renaissance notion of travel. The bourgeoisie in the $18^{\text {th }}$ century invented tourism and travel was no longer an activity for pilgrims and crusaders alone. The bourgeoisie travelled without God and they did it for educational purposes, including trips to areas outside of civilisation. In 1800 J. M. Degérando put it like this: "The philosophical traveller, sailing to the ends of the earth, is in fact travelling in time; he is exploring the past; every step he makes is the passage of an age." (Fabian 1983:7)

Charles Darwin's evolutionism and other theories from the natural sciences, contributed to a concept of time as something both naturalised and linear. Events could be recorded in the order they appeared, and the so-called social Darwinism (more a product of Herbert Spencer than Darwin himself) organised human societies following the same line of thought, with modern Europe at the peak. Also, the relations between different parts of the world were understood as temporal relations. When Europeans travelled, the peoples they met were understood as contemporaries in the restricted sense that they were obviously existing here and now, but at the same time they were still living in some kind of parallel universe - they did not share the same development level. Societies in the far away world represented to the Europeans what we may call present versions or remnants of earlier stages of human development. From this appeared the idea that any- 
one wanting to study man in his pre-modern form could do this through the study of nonEuropean peoples living in the present.

Not only social scientists, but also journalists saw the world like this. One illustration is this article from Siam (Thailand) printed in Morgenbladet. The story presents Siam as a case of pre-modern innocence, still waiting for civilisation through colonialism:

Bright and shiny as the tropic sky, painted golden red from the sinking sun, lies the river, just as it was when I came sailing up [on the ship] "Maha" four months ago. Not one second have I tired of this strange flood with its voluptuous shores and its strange crowds, every passing day has rather revealed more of its beauty and has tied my love for it even harder. Down the Menam river - the life nerve of Siam - glides [the Danish ship] "Siam" large, proud and majestic. From the parade deck, where I have organised a nice little study, I can see both the fertile shores, closing in on the ship. Riches and splendour, voluptuousness, beauty and sunshine shine in my face, wherever I look. The pole houses and the bamboo sheds on the shores are indeed ramshackle and wretched, but they are picturesquely placed under palm trees and mangroves. The brown skinned men and women are indeed almost naked, they barely own what is hanging on their bodies as well as the small canoe, in which they go rowing about, but they are happy and rich because their minds are light as the sun above their heads and they smile like the flowers in the field. They do not store things in a barn, and nothing can disturb their satisfied state of mind. It is easy to envy these people and wish that the shell around ones brain was just as immune to sunburn and that ones mind was just as hardened against grey weather. (Morgenbladet 21.03.1900)

The author goes on contemplating how much he will miss this warm, sunny country back home with his collar turned against that grey cold weather. He also expounds on his political opinions about the situation in Siam, and concludes that it is merely a question of time before the country will "abandon the independent state" and become colonised. The only question is whether Great Britain or France will have "the honour" of colonising Siam and showing it the path to civilization.

One should not underestimate travelling reporters in this period. They were often gone for months, even years, and they knew the societies they were reporting from a lot better than many reporters do today. On the other hand, their professionalism did not include talking to "natives" and they were tremendously confident and assured when it came to generalizing about a people's or a country's character. One case in point is this excerpt from Morgenbladet in 1900. The article is a political analysis about the historical relations between Russia and Persia (Iran), and it characterizes the Persians as follows:

The Persians are described as a handy and extremely alert people with a prominent talent for languages and a great sense of poetry. In hardly any other country has the love for literature penetrated so deeply into a people. The Persian loves his beautiful language, even though his historical knowledge is quite limited. On the other hand the Persians are known to be changeable liars with a lack of personal courage. (Morgenbladet 13.02.1900)

Big, sweeping deliberations about race and folk character were common in this period. It is interesting, however, to notice that such generalisations became less absolute when we leave the distance and move closer to home along the axis between proximity and 
distance. In 1910 Morgenbladet gives a review of a French book called "Le drapeau ou la foi" (The Flag or the Faith). The story is about two French soldiers caught on different sides during the French-German war. The book was particularly praised for the way it described religious and cultural differences:

The author has in an excellent way described the big difference that has evolved between these two men. They originate from the same race, but one has been planted in a foreign country and this leads to such a difference that they have nothing in common. There is nothing French about lieutenant von Sommerhausen anymore. He has acquired the good qualities of the Prussians as well as their flaws... (Morgenbladet 16.03.1910)

The character of a people is thus an ambiguous category. It can be learned and unlearned and it is also contagious. Even between the close at hand and the distant there is a danger of contamination, as pointed out by the delegates to a missionary conference in London 1900:

Mr. Wiloughby spoke about South Africa, where the native population is many times as numerous as the Europeans. He underlined that no high-quality and informed race could live together with a weaker and lowlier one without - if it did not succeed in uplifting the weaker to his own level - falling to the level of the weaker. (Morgenbladet 08.01.1900)

In 1890 Intelligenssedlene brings a horrifying example of how such a contamination process can come about. Henry M. Stanley's Syrian interpreter, Assad Farran, tells about terrible conditions in the Yambuna camp, where the British colonel Barttelot treated the local population in a truly gruesome manner:

He let Jameson and some Sudanese abduct native women and children, and they were not released until the men could present goats and poultry as ransom. Some women tried to run away during the night. To prevent this they were tied to trees with ropes around their necks and arms during the day, and at night led to the officer's quarters. Major Barttelot often treated the Sudanese soldiers with inhumane cruelty. Four Sudanese, who stole an axe and sold it for food, each received 150 whippings. He dictated 100, 50 or 25 whippings for quite insignificant misdemeanours. Not even towards the sick did the Major show any mercy. (Norske Intelligenssedler 21.11.1890)

Farran goes on to describe two British citizens that have "gone wrong". It should however be noted that no generalizing statements about whether or not this kind of brutality was a basic trait of the British character accompanied these descriptions. What we find is rather a parallel to Joseph Conrad's "Heart of Darkness", more specifically as to how barbaric surroundings can corrupt an otherwise civilised human being:

Jameson...once had a conversation with Tippo Tipp [a local chief]. The subject of cannibalism came up, and Jameson disclosed that he had heard a lot about such things in England, and that he would have a great deal of interest in witnessing how the cannibals went about their business. (ibid)

Jameson finally pays Tippo Tipp six cotton scarves for a young girl and lets her get eaten, all the while making pencil sketches that he later colours.

The story arouses disgust and negative feelings towards Jameson and his kind, but there is a paradox that should be noted: Even if the terrible act was bought and paid for 
by a violent European brute, the text shows no doubt about the fundamentally barbaric spirit of the Africans who apparently committed crimes like this on a regular basis.

This is also one of many examples that show how bringing development to remote corners of the world was portrayed as a necessity, and although development was considered the inevitable result of history in the making, the Europeans were needed to speed things up. Time - as development - was something we controlled, not they. As a case in point, Morgenbladet describes a dispute between a Norwegian consul and the authorities in Brazil over his export of a particular flour for children that the Brazilians said contained salicylic acid. The Norwegian won the case, even if it took some time, and the Norwegian Technological Association invited him to speak to its members. The consul amused his audience with stories about the slow witted ways of Brazilian civil servants, and informed them about the country in general:

Brazil has great possibilities. It is a country of rare fertility. But the Brazilians are basically an indolent people without initiative, and the constant mixture of black and white elements of the population has resulted in a group of people, the mulattoes, who do not contribute to the development of the country. While Brazil over the last years has made great progress in many fields, this is largely due to immigrant businessmen. (Morgenbladet 16.03.1910)

\section{A Domestic World}

The press is supposed to serve its audience with topical and relevant information. These requirements have not changed between 1880 and 2006. A good journalist is someone with "a good nose", who feels the pulse of the time, who knows his or her contemporaries, be they close or afar. Areas perceived as close are, however, seen as more dynamic, with time ticking a way a lot faster than in more distant areas. The more dynamic, the more coverage and the more ambiguity are allowed.

The period between 1880 and 1930 covers a wide range of greater and smaller technological revolutions and innovations, making the world more accessible than ever before. This development tied people together across the world, but it also created a wider gap between "us" (as a group of contemporaries) and peoples living far away.

Because the world is constituted domestically, in local newsrooms, by journalists thinking about their local audiences, international news is not necessarily very new. It is easier to spot what happens in the shady distance when it corresponds with already established notions. Something actually new may not fit people's preconceptions as effortlessly, leading to the misconception that places far away - like Africa and Asia are static places where nothing much happens.

The concept of distance needs, however, to be understood in historical and political terms, as Norwegian-Swedish relations before and after 1905 show. Political relations, as well as both local and international power relations are just as important as geography when it comes to what is considered close on the axis between proximity and distance. The way the world was presented to Norwegian readers is thus not only a result of the information available to the editors, but also the outcome of what the newspapers wanted or were able to see. 


\section{Notes}

1. The full survey is presented in Pressehistoriske skrifter no 6, 2006.

2. The name, Norske Intelligenssedler, is spelt differently in different historical periods but stays the same, until the newspaper is merged with Tidens Tegn in 1920. Norske Intelligenssedler has been kept throughout the research period to avoid confusion.

3. The article has been shortened. The point is to show how important it was to indicate how the story moved from place to place, not its content.

4. According to Schütz, Umwelt is the core area of life - that which is within reach here and now, like people you can see and talk to directly. Mitwelt is the group of contemporaries, while Vorwelt represents the past and Folgewelt the future. (Schütz in Johansen, 1995:116)

\section{Litterature}

Anderson, Benedict (1983) Imagined Communities: Reflections on the Origin and Spread of Nationalism. London: Verso.

Fabian, Johannes (2002) Time and the Other. New York: Columbia.

Johansen, Anders (1997) Gratie. Oslo: Tiden.

Johansen, Anders (1995) 'Medmennesker, landsmenn, samtidige', Norsk medietidsskrift 1. 113-143. Oslo: Novus.

Kern Stephen (1983) The Culture of Time and Space 1880-1918. London: Weidenfeld and Nicolson.

Lien, Marianne (1997) Marketing and Modernity. Oxford: Berg.

Nustad, Knut (2003) Gavens makt. Oslo: Pax.

Ricoeur, Paul and Ystad, Hallvard (1999) Eksistens og hermeneutikk. Oslo: Aschehoug.

Schütz Alfred (2002) Den sociala världens fenomenologi. Göteborg: Daidalos.

Tjelmeland, Hallvard (2004) Aviser som historisk kjelde, Pressehistoriske skrifter 3/2004, 114-131, Oslo: IMK.

ANNE HEGE SIMONSEN, Cand.Polit., Associate Professor, Faculty of Journalism, Library and Information Science, Oslo University College P.O. Box 4, St. Olavs plass, NO-0130 Oslo, annehege.simonsen@jbi.hio.no 